\title{
Intergenerational Sexual Relationship in Nigeria: Implications for Negotiating Safe Sexual Practices
}

\author{
Oyediran, K.A., Odutolu, O. and Atobatele, A.O. \\ MEASURE Evaluation/JSI, World Bank/Nigeria and USAID/Nigeria \\ Nigeria
}

\section{Introduction}

In Nigeria, young people aged 15-24 years old contribute significant number to the new HIV infections with the majority of those infections occurring in young women and girls. From NARHS 2007, HIV prevalence rate among young women is approximately 2.5 times that of young men within the age group. This disproportionate rate of HIV infection in young women is similarly found in many other countries in sub-Saharan Africa. For instance, data show that in general young women age 15-24 in sub-Saharan Africa are three times more likely to be infected with HIV than young men of the same age (UNAIDS, 2006). In Zambia and Zimbabwe, young women are four and five times respectively more likely to have HIV infection compared to their male counterparts (UNAIDS 2004). While biological factors may account for women's greater susceptibility to HIV; the difference is marked and cannot be explained on the basis of biology alone. It therefore raises the question of differences in sexual behaviour among the group within the context of cultures; lifestyle; and structural and environmental factors. As a result of this alarming HIV infection, the sexual behavior of this population is of great public health concern.

Within this premise and in order to understand the sexual behaviour of young women, intergenerational sex has been widely explored in literature. There is clear empirical evidence that age-mixing between young women and older men plays an important role in the differences in the observed epidemiological pattern (Gregson et al., 2002). Studies indicate that relationships between young women and older men are common in many parts of sub-Saharan Africa and are significantly related with unsafe sexual behaviour and increased vulnerability to HIV infection (Glynn et al., 2001; Kelly et al., 2003; Longfield et al., 2004). For instance, Langeni (2007) in the study of 800 men in Botswana found that for every year's increase in the age difference between partners there was a 28 percent increase in the odds of having unprotected sex. Similar studies reveal that such relationships are largely premised upon material gains, the greater the economic asymmetries between partners and the greater the value of a gift, service, or money exchanged for sex, the less likely the practice of safer sex (Luke, 2003; Wojciki, 2005). In this regard, intergenerational sex is similar to transactional sex because sex is exchanged for money and other materials, but the concept of intergenerational sex is clearly differentiated from commercial sex or 
prostitution. The former is based on material support mainly through relationships with 'sugar daddy or sugar mummy' (Moore \& Biddlecom, 2006).

\section{Intergenerational sex}

Intergenerational sex is similarly referred to as cross-generational sex or age-mixing or agedisparate relationships in literature. It is a pattern of sexual behaviour between young women and older men within or outside of marriage. The term suggests wide variation in the ages of the partners with the men being commonly the older partner. The phenomenon is observed also between young men and older women; but this is less common, less overt and has not been linked with high HIV prevalence among the young men. Intergenerational sex has been more clearly defined, within both the UNAIDS general population survey and the Demographic and Health Surveys (DHS) AIDS modules, as 'Young women ages 15 to 19 who "have had non-marital sex in the last 12 months with men who are 10 or more years older than themselves." But the definition is being expanded to include sexual relationships in which the age difference between the partners is only five years by other researchers. This revision is based on the observation that having sexual relations with a man only five years older has been clearly associated with increased risk of HIV in girls.

The practice of intergeneration sex is pervasive and is inherent in many cultures and traditions. Although, intergenerational sex is not limited to sub-Saharan Africa, the high prevalence of HIV infection in the region, especially among young adults, has led to studying behaviours that are associated with increased incidence thus making most available data on the practice to be in the region as it is associated with a higher risk of HIV infection. Furthermore, relationships between young women and older men are considered to be the norm in some cultural contexts. However, women in sexual relationships with older male partners have been found to have poor reproductive outcomes, including increased risk for HIV infection (Kelly, et. al., 2003; Gregson, et. al., 2002; Jewkes, et. al., 2002). Dissassortive sexual age mixing patterns can provide entryway for HIV and STIs into the younger generation (Jewkes, et. al., 2002). In the context of poverty and gender inequality, intergenerational sex often involves sex in exchange for money or goods and characterised by less condom use and greater sexual coercion (Gregson, et. al., 2002; Luke, 2005; Longfield, et. al., 2004). The risks associated with intergenerational sex may be, in part, due to the power imbalances between the partners (Blanc, 2001; Mensch and Lloyd, 1998). Particularly if a young woman is dependent on an older man for financial support, she may have little power to negotiate safe sex (Luke and Kurz, 2002). Furthermore, in instances where a young woman does assert herself, she may face sexual and physical violence (Kaufman and Stavrou, 2002; Wood, Maforah and Jewkes, 1998).

Several factors have been identified within age-mixing relationships that increase the risk of sexually transmitted infections (STIs) and HIV infection. Firstly, for both partners risk perception is often very low. According to Longfield et al. (2004), men in Kenya often report a preference for young sexual partners, basically because they are adjudged more likely to be free from HIV infection. While in South Africa, young women viewed older men in much the same way; as 'safe' partners because they appear to be less risk-taking, more stable and more responsible (Leclerc-Madlala, 2003). Young women are also found to be more concerned about the risk of becoming pregnant or of being 'found out' in their relationships with older men, than of STI or HIV (Silberschmidt and Rasch, 2000; Jones, 2006; Nkosana and Rosenthal, 2007). Secondly, in this relationship of unequal partners, young women's 
power to negotiate condom use is often compromised by age disparities and economic dependence. Young women have reported that they often cannot insist on safe sex practices, and doing so would jeopardize their economic goals in the relationships (Glynn, et. al., 2001; Luke, 2005; Longfield, et. al., 2004). According to a 17 year old out of school Ugandan young woman who was 15 years younger than her partner:

'He would pick me from home secretly and take me for film

shows in town. I would always lie to my mother that I had

gone to my Auntie's place and would spend nights with him.

At the end of it all he asked me to show him that I loved him

by having sex with him and I complied. I could not refuse

because I was ashamed of all the things he had done for me.'

(Moore and Biddlecom 2007)

The young women oblige to have sex within the relationship more out of a feeling of 'pay back' or appreciation of what the man has done or being in a position to meet his needs, more or else taking responsibility to please him. Men are also known to threaten to abandon the young women for another. The next section explores these and other reasons why the practice has continued to thrive despite the risk of STI and HIV infection.

\subsection{Reasons for engaging in intergenerational sex}

Several qualitative and few small-scale quantitative studies have explored factors luring young girls to engaging in intergenerational sexual relations in sub-Saharan Africa. Studies from Cameron, Kenya, Nigeria, Tanzania, Ghana, Swaziland and Uganda among others find that young women engage in sexual relationship with older partners for economic survival; funds to cover education-related expenses; enhanced status and connections in social networks; improved life opportunities and options; security; love and probably the option of marriage(Calves et al., 1996; Weiss et. al., 1996; Komba_Malekela and Lijestorm, 1994; Nyanzi, et. al., 2000; Akuffo, 1987; Stavrou and Kaufman, 2000; Gage, 1998; Orubuloye, et. al., 1992; Meekers and Calves, 1997). Scholars have documented that girls are motivated to engage in sexual relations with older partners due to their perceived view that older men are marriageable types and more likely to marry or support them in case of unintended pregnancy (Weiss, et. al., 1996; Komba-Malekela and Liljestrom, 1994; Nyanzi, et. al., 2000; Gorgen, et. al., 1998). Also of significant importance is the fact that parents often pressurize girls to form relationships with older, established partners that may lead to marriage - or at least where the partner can support their daughter if she becomes pregnant unintentionally (Gage, 1998). As shown by other studies, parents could indirectly encourage the relationship by warning their daughters not to bear a poor boy's child (Gorgen, et. al., 1998; Gorgen, et. al., 1993). On the other hand, parents disapprove of girls' relationship with older men when observed that the man is not interested in marriage (McLean, 1995).

A study conducted in Swaziland among girls 14 years and older reported that 20 percent of the girls reported being sexually active because of financial reasons (McLean, 1995). Another study in rural Tanzania found that 52 percent of female primary school students and 10 percent of female secondary school students reported that the reason for having sex was for money or presents (Matasha, et. al., 1998). In addition, in a study in rural Ghana, the majority of both in-school and drop-out girls admitted that the most important reason for having boyfriends was financial, and a further one-third said the reason was for the purchase of clothing and other goods (Akuffo, 1987). With respect to economic survival, 
evidence from several studies indicates that many girls need resources from older men for basic needs or in times of economic crisis (MacPhail and Campbell, 2001; Stavrou and Kaufman, 2000; Feldman et. al., 1997). For instance, scholars reported that parents may directly pressurize their daughters to enter into relationships with older, well-off men because they demand assistance from their children, including the money given to girls by their older partners (Gage, 1998; Komba-Malekela and Liljestrom, 1994). Furthermore, numerous studies point to adolescent girls' motivations to secure life opportunities and enhance long-term goals of higher economic status and security through their involvement with older partners. Stavrou and Kaufman (2000) and Abang (1996) reported that some young women engage in relations with older partners to help pay for tuition, living expenses, university housing, clothes and food. Scholars further observed that older partners of young women help them to meet prestigious people and establish themselves in an occupation or career (Gage, 1998; Meekers and Calves, 1997a, 1997b; Orubuloye, et. al., 1992).

Evidence from a few relatively small-scale quantitative studies indicated that sociodemographic attributes could be used to explain the context of cross-generational sex. In Lesotho, an important finding is that there is a strong relationship between wealth index and urban-rural residence and the likelihood of engaging in intergenerational sexual partnerships: women in lower wealth quintiles and in rural areas are more likely than others to engage in cross-generational partnerships (ORC, Macro, 2007).

\subsection{Intergenerational sex and HIV infection}

Evidence from the literature clearly links intergeneration sex with high HIV infection in young women. Young women who engage in sexual relationship with older men are more likely to have HIV infection compared to their male counterparts who do not. A study in rural Rakai, Uganda (Kelly, et. al., 2001) analyzed the relationship between HIV prevalence and the age of adolescent girls' primary sexual partner, whether marital or non-marital. In a multivariate analysis, among girls aged $15-19$, the adjusted relative risk of HIV infection doubled among those reporting a most recent sexual partner 10 or more years older, compared to those with partner 0-4 years older. Among young women $20-24$, the adjusted relative risk of HIV infection was 24 percent greater, and among young women aged 25 - 29, it was 9 percent lower. Additional results suggest that 12.4 percent of the HIV prevalence in girls aged 15 - 19, and 5.1 percent in young women aged 20-24, can be attributed to relationships with men 10 or more years older, largely within marital relationships. Another study in rural Zimbabwe (Gregson, et. al., 2002) also finds a significant positive effect of age difference, with most recent marital or non marital partner; on HIV infection for all adolescents aged $17-24$. In a multivariate analysis, the authors conclude that a one-year increase in age difference between partners is associated with a 4 percent increase in the risk of HIV infection. In a related analysis of the effect of age difference between partners in town urban cities in Africa: Kisumu, Kenya and Ndola, Zambia, Glynn et. al. (2001) find a significant positive association between larger age difference with husband and HIV infection. The authors reported that for girls with less than a four-years age difference with their husbands, none are infected with HIV, whereas 38 percent in Kisumu and 34 percent in Ndola are infected if the age difference with their husbands is four years or greater.

In the Nigerian context, there are empirical evidences of intergenerational sexual relationships; the 2003 DHS reported that the prevalence of intergenerational sex among girls aged $15-17$ years is $21.3 \%$ percent. This represents the highest prevalence among the 
countries shown in a table 1 below. Significantly there is the practice of early marriage in the northern part of the country and more often than not the young women are married to men who are much older than themselves. In general terms the practice is cultural; so also is polygamy. Could it be a situation of double jeopardy? Unfortunately, the subject has not been well researched as to its implication on STI and HIV infection.

\section{RECENT DHS SURVEYS ON INTERGENERATIONAL SEX}

\begin{tabular}{|l|r|l|}
\hline Country, Year of DHS & $\begin{array}{l}\text { Percentage of sexually } \\
\text { active women aged 15-17 } \\
\text { with partner at least 10 } \\
\text { years older in the past year }\end{array}$ & $\begin{array}{l}\text { Percentage of sexually } \\
\text { active women aged 18-19 } \\
\text { with partner at least 10 years } \\
\text { older in the past year }\end{array}$ \\
\hline Ghana 2003 & 1.7 & 7.9 \\
\hline Nigeria 2003 & 21.3 & 4.2 \\
\hline Malawi 2004 & 0.9 & 2.4 \\
\hline Tanzania 2004 & 4.9 & 7.8 \\
\hline Lesotho 2004 & 7.5 & 7 \\
\hline Uganda 2004-2005 & 9.4 & 9.9 \\
\hline
\end{tabular}

Source: DHS Reports ORC MACRO

Table 1. Recent DHS Surveys on intergenerational sex

Consequently, there is a knowledge gap on the spread of the practice; factors promoting the practice; the ability of the young women to negotiate safe sex and HIV infection in the age group. Hence, understanding the underlying factors and prevalence of the intergenerational sex is a priority study for Nigeria. The main thrust of this paper is to examine the prevalence of, and factors associated with intergenerational sexual relationship among young women aged 15 - 24 years and examine the implications of the practice on safe sex and HIV infection. The study will analyze the 2008 Nigeria Demographic and Health Survey (NDHS) to explore the relationship between young women's individual socio-demographic attributes and behaviour. Lastly, the paper will proffer programmatic and policy recommendations.

\section{Methods}

This study used data from the 2008 Nigeria Demographic and Health Survey (NDHS), which was carried out by ORC Macro and the National Population Commission. The sample was selected using a stratified 2-stage cluster design consisting of 888 clusters taken from a list of enumeration areas developed for the 2006 Population Census. A nationally representative probability sample of 36,800 households was then selected from the clusters, with a minimum target of 950 completed interviews per state, in which all women aged 15 to 49 years were eligible to be interviewed. The men's questionnaire was administered to all men aged 15 to 59 years in a sub-sample of half of the households. The survey collected information between June and October 2008. The data are intended to furnish program 
managers and policy makers with detailed information on the levels and trends in fertility; nuptiality; sexual activity; fertility preferences; awareness and use of family planning methods; infants and young children feeding practices; nutritional status of mothers and young children; early childhood mortality and maternal mortality; maternal and child health; and awareness and behavior regarding HIV/AIDS and other sexually transmitted infections. The data also provided information on malaria prevention and treatment; neglected tropical diseases; domestic violence; fistulae and female genital cutting.

Since the main thrust of this paper is to examine the prevalence of, and factors associated with intergenerational sexual relationship among young women aged 15 - 24 years; we examined the relevant questions within the survey to provide information on the indicators. Specifically, young women age $15-24$ who had sex with a non-marital, non-cohabiting partners in the 12 months prior to the survey were asked whether the man was younger, about the same age, or older than they were. If older, they were asked if they thought he was less than ten years older or ten or more years older. The analysis was restricted to those who had sexual relationship with a man who was 10 or more years older than them.

The dependent variable was binary and defined as the occurrence of the young women aged 15 - 24 years reporting having had sex with non-marital and non cohabitating male partners in the past 12 months who are at least 10 years older and those who did not. Possible confounders and other independent variables identified through the literature and theoretic reasoning fell into two (2) main groups: socio-economic and behavioural variables. In the first group were length of time away from home, place of residence (urban/rural), religion, ethnicity, regions, age, and educational attainment. While variables such as age at sexual debut, age difference between respondent and her first sexual partner and frequency of media exposure were considered in second group. Demographic, socio-economic and behavioural variables were included in the analysis to identify factors for possible intervention and to act as control variables in the analytical models.

The data analysis employed both descriptive and analytical techniques. Both descriptive and analytical analyses were conducted to ascertain the association and net effect of the respondents' background characteristics and identified confounders on the dependent variable (intergenerational sex) when controls for the selected background characteristics were introduced. The statistical analyses were undertaken in two phases. The descriptive statistics show the distribution of respondents by the key variables, and in the bivariate analysis, the relationship between each explanatory variable and the dependent variable was examined. Finally, multivariate logistic regression analysis was utilized to examine the net effects of the variables on the likelihood of having an intergenerational sexual relationship. First, socio-demographic characteristics and behavioural factors thought to be related to the intergenerational sexual relationships were examined using a Pearson $x^{2}$ test.

Multivariate logistic regression analyses were performed to calculate the adjusted odds ratios (ORs) and 95\% confidence intervals (CIs) for predictors of women reporting high-risk sex within the last 12 months with older men of at least 10 years and older. Four structured regression models were estimated to describe the likelihood that a young woman would have had intergenerational sex when the different categories of the covariates are statistically controlled. Model 1 treats the likelihood of intergenerational sex as a function of the basic socio-economic variables (age, education, wealth index). Model 2 adds measures of socio-cultural influences (place of residence and ethnicity). The third model adds measures of attitudes and behavioural factors (age at sexual debut and age difference between 
respondent and her first sexual partner). Finally, model 4 adds a measure of media exposure (frequency of watching television) and socio-cultural influence (region). This analytical procedure provides an opportunity to examine how each set of explanatory factors is associated with young women's engagement in intergenerational sex.

Logistic regression was used in determining the effects of predictor variables on the outcome variable (intergenerational sexual relationship). The logistic regression model also offers ease of interpretation through the use of odds ratios. The logistic regression function has the form In $(p / q)=B_{0}+B_{1} X_{1}+\ldots+B_{k} X_{k}$, where $p$ is the probability that a respondent who engaged in higher risk sexual relationship with a man 10 years or more older; $q$ (or 1-p) is the probability that the respondent did not have sex with a man 10 years or more older in the past 12 month prior to their interview. $B_{0}, B_{1}, \ldots B_{k}$ are regression coefficients, and $X_{1}, X_{2}$, $\ldots X_{k}$ are factors. The exponential of the regression coefficients of the parameter estimated gives the odds ratios in the logistic regression models, which is interpreted as the likelihood of intergenerational sex under the given scenario

\subsection{Variable definition and relations}

As earlier stated, the 2008 NDHS questionnaire elicited information on sexual activity with non-marital partners and in the 12-months preceding the survey and whether the male sexual partner is 10 years older. The dependent variable, intergenerational sex, - defined as relationships between younger women and older men who are 10 or more years older in the last 12-months. The operational variables include age, ethnicity, place of residence, wealth index (poverty proxy), education, region, age difference between respondent and her first sexual partner and age at sexual debut. The socio-cultural and demographic variables were transformed either into categorical or dichotomous variables and entered as dummy variables in the multivariate analysis.

It is hypothesized that intergenerational sexual experience will decrease with age. Because the younger the girl experiencing sex, the older her partners will be and presumably by age 18, many of the girls would be ceasing the relationship with the much older partner and have taken a sexual partner closer to their own age which may likely be their permanent suitor. Current age of respondents is grouped into four categories (15 - 17; 18- 21 and 22 - 24) and the likelihood of having intergenerational sexual relationship is expected to decrease with age. Age at sexual debut is included as an explanatory variable because it has been found to be significantly associated high risk sexual behavior (Gomez, et. al., 2008). It is therefore necessary to explore whether this association holds among Nigerian girls. Age at first sexual encounter is sub-divided into four categories: below 15, 15 - 17, 18 years and older.

Religion is believed to have a profound impact on the behaviour and viewpoint of individuals. Even in the face of modernization and its consequences on cultural practices, religion still seems to hold a firm grip on moral values relating to sexual practices and behaviour. Therefore, girls who are more religious are more likely to hold strong, rigid, and fundamentalist religious beliefs that may discourage their sexual escapades before marriage in order to remain virgin. However, the relationship between religious affiliation and sexual practices, particularly intergenerational sex, is likely to be mediated by social and demographic factors, such as education of the respondent and region of residence. The religious affiliation sub-groups used are Catholic, Other Christians and Islam.

Ethnicity is an important proxy of cultural factors affecting sexual behaviour since it encompasses values and norms that govern the behavioural and psychological aspects of social interaction between men and women in a particular socio-cultural space. It may also 
reflect the level of openness to influences of and/or adherence to other cultures due to interactions with different areas and/or regions. With more than 389 ethnic groups in Nigeria, ethnic differences are critical in explaining cultural differences and behavioural patterns, including sexual relations and practices. Also the heterogeneity of ethnic groups in Nigeria implies that social changes takes place at different paces and in a non-uniform manner since some ethnic groups may be more receptive to change than others. For this paper, ethnic affiliation is categorized into five sub-groups based on their numerical strength and affinity. The ethnic sub-divisions used are Igbo, Yoruba, northern minorities, southern minorities and others due to small number of cases for Hausa/Fulani ethnic group. The northern and southern minorities comprise numerous smaller ethnic groups in the north and south respectively while other ethnic group consist mainly small tribe with less than 2 percent of the country population, whose sample sizes were too small to stand alone in the analysis. This analytical convenience, however, does not suggest that each of the two broad ethnic groupings is homogeneous in their socio-cultural environment or behaviour.

In view of the paucity of research on regional differential in intergenerational sex, it is significant in this paper to explore the phenomenon within the 2008 NDHS data that contain comparable and representative regional information. Apart from underscoring the structural patterns within the Nigerian community, region represents differences in the socio-economic and cultural influence on respondent sexual practices, particularly intergenerational sexuality. It is important also to note that regions constitute a proxy for social change or development. In this paper, Nigeria is sub-divided into two distinct geopolitical regions namely; Northern and Southern region. Place of residence is also included to capture the influence of urban and rural residence on the likelihood of intergenerational sex.

It is hypothesized that younger women at lower wealth quintile are more likely to engage in intergenerational relations than those at higher wealth quintiles. However, this relationship depends on the interplay of several other confounding factors such as age of the respondent, educational attainment, and place of residence. Since studies have reported a key motivational factor while young girls engage in sexual activity with older men is because of their economic status (Gage, 1998; Orubuloye, et. al., 1992; Meekers and Calves, 1997) it is important to see whether wealth index as constructed in the NDHS could help shed light on the interplay of poverty with intergenerational sexual relationships. Wealth index was constructed from the household facilities and ownership of a certain consumer items such as television, radio, bicycle, car, as well as dwelling characteristics such as source of drinking water, power supply, type of sanitation facilities, and type of material used in flooring and roofing the dwelling units. Each household was assigned a score for each asset, and the scores were summed up; individuals were ranked according to the total score of the household in which they resided. The aggregate scores were then divided into quintiles, from one to five, corresponding to the poorest and the wealthiest groups.

Educational attainment was categorized as less than secondary education, secondary education and post-secondary education. Residence and region were included based on the method of sampling used by the NDHS. Although original sampling was performed using the 37 states, the analysis included regions because of the relatively few number of cases in some states and risk of non-convergence in the multivariate statistical methods. Finally, media exposure was categorized according to self-reported frequency of watching, listening to, or reading the television, radio, or newspapers/magazines. 


\subsection{Respondents' profile}

A total of 12, 649 young females, aged 15-24 years were interviewed during the 2008 NDHS and 2,029 of these young women who engaged in higher-risk sexual intercourse in the past 12 months were analyzed in this study. The basic-demographic characteristics of the study population are provided in Table 2. About 44 percent of them were 15-19 years of age while the remaining 56.5 percent were aged 20-24 years. The median age of the respondents was 20.0 years. The survey indicated that 6 out of 10 of the respondents resided in rural areas and regional spatial distribution of the study population shows that 74.1 percent of them resided in the southern regions of South-east, south-south and south-west, while the remaining 25.9 percent resided in the three-regions in the northern part of the country. The distribution of respondents by ethnic affiliation shows that 12.9 percent are Igbo, 13.0 percent are Yoruba; 1.1 percent are Hausa/Fulani; minority ethnic groups constitute 26.5 percent. Of the minority ethnic groups, the northern minorities constitute 5.0 percent of the respondents, while southern minorities constitute 21.5.0 percent. Other ethnic groups in Nigeria with population less than 1 percent of the country population constitute 33.1 percent Majority (73.4 percent) of the young women under study had secondary education. While about 15 per cent of them had post-secondary education, 9.7 percent and 2.1 percent had primary education and no formal education respectively. Christians constituted a majority of the sampled population with about nine out of ten young females being Christians. Muslims constituted 12.4 per cent. Another important background characteristic considered in the analysis was the wealth quintile. Wealth quintile constructed from the household facilities is used as a proxy for economic status. The level of wealth quintile ranges from the first to the fifth quintile, corresponding to the least and most well off respectively. The Wealth quintile revealed that about one out of four young women were from households classified in the fifth quintile.

Table 2 reveals a high level of exposure to electronic media. Three out of ten of the respondents listened to the radio at least once in a while and about 32.6 percent of young women who engaged in higher-risk sexual intercourse in the past 12 months reported listening to the radio every day. About a quarter (22.7 percent) had never watched television; while 37.7 percent watched television every day. The reading of newspaper or magazine is low among the study population. Over half 56.3 percent had never read newspaper or magazine while 4.5 percent read newspaper or magazine every day. The results indicate widespread access to media.

Table 2 further compared the characteristics of sexually experienced young women and those among them that engaged in higher-risk sexual intercourse in the preceding 12 months before the survey. The result reveals that there is no major difference between those who are sexually experienced and those among them engaged in higher-risk sexual relationship with men ten years or more years older than them. For instance, 43.5 percent of those who had intergenerational sexual relationships are 15 - 19 as compared with 37.9 percent of the counterparts that are sexually experienced. The median age for both subgroups was 20.0 years. Furthermore, those young women who engaged in higher-risk sexual intercourse are likely to reside more in urban areas; reside more in southern regions, more educated, come from more affluence households, belong to Christian religious especially those who are protestants or Pentecostals and have more access to the media than sexually experienced young women age 15 - 24 interviewed during the 2008 NDHS. 


\begin{tabular}{|c|c|c|c|}
\hline Characteristics & $\begin{array}{l}\text { Number } \\
(\mathrm{N}=7,979)\end{array}$ & $\begin{array}{l}\text { Percentage of women } \\
\text { age } 15-24 \text { who had had } \\
\text { sexual experience }\end{array}$ & $\begin{array}{l}\text { Percentage of women age } 15 \text { - } \\
24 \text { who had high-risk sexual } \\
\text { intercourse in the past } 12 \\
\text { months }(\mathrm{N}=2,029)\end{array}$ \\
\hline $\begin{array}{l}\text { Age group } \\
15-19 \\
20-24\end{array}$ & $\begin{array}{l}3,021 \\
4,958\end{array}$ & $\begin{array}{r}37.9 \\
62.1(20.0)\end{array}$ & $\begin{array}{r}43.5 \\
56.5(20.0)\end{array}$ \\
\hline $\begin{array}{l}\text { Place of residence } \\
\text { Urban } \\
\text { Rural }\end{array}$ & $\begin{array}{l}2,137 \\
5,842\end{array}$ & $\begin{array}{l}26.8 \\
73.2\end{array}$ & $\begin{array}{l}40.3 \\
59.7\end{array}$ \\
\hline $\begin{array}{l}\text { Region of residence } \\
\text { Northern } \\
\text { Southern }\end{array}$ & $\begin{array}{l}5,016 \\
2,903\end{array}$ & $\begin{array}{l}63.6 \\
36.4\end{array}$ & $\begin{array}{l}25.9 \\
74.1\end{array}$ \\
\hline $\begin{array}{l}\text { Ethnicity } \\
\text { Hausa/Fulani } \\
\text { Igbo } \\
\text { Yoruba } \\
\text { Southern minority } \\
\text { Northern minority } \\
\text { Others }\end{array}$ & $\begin{array}{r}2,834 \\
793 \\
886 \\
725 \\
611 \\
2,101\end{array}$ & $\begin{array}{r}35.7 \\
10.0 \\
11.1 \\
9.1 \\
7.6 \\
26.4\end{array}$ & $\begin{array}{r}1.1 \\
18.3 \\
21.0 \\
21.5 \\
5.0 \\
33.1\end{array}$ \\
\hline $\begin{array}{l}\text { Educational level } \\
\text { No education } \\
\text { Primary } \\
\text { Secondary } \\
\text { Tertiary } \\
\end{array}$ & $\begin{array}{r}3,280 \\
1,220 \\
3,030 \\
449 \\
\end{array}$ & $\begin{array}{r}41.1 \\
15.3 \\
38.0 \\
5.6 \\
\end{array}$ & $\begin{array}{r}2.1 \\
9.7 \\
73.4 \\
14.8 \\
\end{array}$ \\
\hline $\begin{array}{l}\text { Religious affiliation } \\
\text { Catholic } \\
\text { Other Christians } \\
\text { Islam } \\
\text { Traditional/Others } \\
\end{array}$ & $\begin{array}{r}767 \\
2,939 \\
4,108 \\
121 \\
\end{array}$ & $\begin{array}{r}9.7 \\
37.0 \\
51.8 \\
1.5 \\
\end{array}$ & $\begin{array}{r}16.5 \\
70.3 \\
12.4 \\
0.4 \\
\end{array}$ \\
\hline $\begin{array}{l}\text { Wealth quintile } \\
\text { First } \\
\text { Second } \\
\text { Third } \\
\text { Fourth } \\
\text { Fifth }\end{array}$ & $\begin{array}{l}2,032 \\
1,745 \\
1,547 \\
1,583 \\
1,072\end{array}$ & $\begin{array}{r}25.3 \\
21 . .9 \\
19.4 \\
19.8 \\
13.4\end{array}$ & $\begin{array}{r}7.7 \\
13.5 \\
21.1 \\
31.2 \\
26.5\end{array}$ \\
\hline $\begin{array}{l}\text { Frequency of watching } \\
\text { television } \\
\text { Never } \\
\text { Less than once a week } \\
\text { At least once a week } \\
\text { Almost everyday }\end{array}$ & $\begin{array}{r}4,403 \\
867 \\
1,068 \\
1,603 \\
\end{array}$ & $\begin{array}{l}55.4 \\
10.9 \\
13.4 \\
20.2\end{array}$ & $\begin{array}{l}22.7 \\
16.5 \\
23.1 \\
37.7\end{array}$ \\
\hline $\begin{array}{l}\text { Frequency of listening } t \\
\text { radio } \\
\text { Never } \\
\text { Less than once a week } \\
\text { At least once a week } \\
\text { Almost everyday } \\
\end{array}$ & $\begin{array}{l}2,848 \\
1,222 \\
1,820 \\
2,059 \\
\end{array}$ & $\begin{array}{l}35.8 \\
15.4 \\
22.9 \\
25.9 \\
\end{array}$ & $\begin{array}{l}19.3 \\
17.4 \\
30.8 \\
32.6 \\
\end{array}$ \\
\hline
\end{tabular}

Note:-Median age of respondent are indicated in the bracket

Table 2. Percentage distribution of young women (aged 15-24 years) sexually experienced and those who had high-risk by selected socio-demographic characteristics (NDHS 2008) 


\subsection{Prevalence of intergenerational sex in Nigeria}

Nearly one in six $(2,029$ of 12,694$)$ of the young women included in the survey reported having higher-risk in the preceding 12 months before their interview during the 2008 NDHS. The results presented in Table 3 show that among women age $15-24$ who had higher-risk sexual intercourse in the 12 months preceding the survey, 14.6 percent had higher-risk sex with a man ten or more years older than them. The median age of sexual debut among the young women who had engaged in higher-risk sexual intercourse in the past year was 17 years. The analysis reveals that the proportions of respondents who had intergenerational sex in the past 12 months before the survey interview decreased with age. For instance, 16.5 percent of young women age 15-17 years, 15.2 percent of those age $18-21$ years and 12.6 percent of their older peers aged 22-24 years had engaged in higher-risk sexual behaviour in the 12 months with a man 10 years or more years older.

\begin{tabular}{|c|c|c|}
\hline Characteristics & $\begin{array}{l}\text { Number of women age } 15-24 \\
\text { who had high-risk sexual } \\
\text { intercourse in the past } 12 \text { months }\end{array}$ & $\begin{array}{l}\text { Percentage of young } \\
\text { women age } 15-24 \text { who had } \\
\text { high risk sexual } \\
\text { intercourse with a man } \\
10+\text { years }\end{array}$ \\
\hline $\begin{array}{l}\text { Age group* } \\
15-17 \\
18-21 \\
22-24\end{array}$ & $\begin{array}{l}407 \\
950 \\
672\end{array}$ & $\begin{array}{l}16.5 \\
15.2 \\
12.6\end{array}$ \\
\hline $\begin{array}{l}\text { Place of residence** } \\
\text { Urban } \\
\text { Rural }\end{array}$ & $\begin{array}{r}818 \\
1,211\end{array}$ & $\begin{array}{l}12.5 \\
16.0\end{array}$ \\
\hline $\begin{array}{l}\text { Region*** } \\
\text { Northern } \\
\text { Southern }\end{array}$ & $\begin{array}{r}526 \\
1,503\end{array}$ & $\begin{array}{l}24.1 \\
11.2\end{array}$ \\
\hline $\begin{array}{l}\text { Ethnic affiliation }{ }^{* * *} \\
\text { Igbo } \\
\text { Yoruba } \\
\text { Northern Minority }^{1} \\
\text { Southern Minority } \\
\text { Others }\end{array}$ & $\begin{array}{l}370 \\
426 \\
124 \\
435 \\
671\end{array}$ & $\begin{array}{r}17.0 \\
7.0 \\
20.2 \\
10.3 \\
19.8\end{array}$ \\
\hline $\begin{array}{l}\text { Educational attainment*** } \\
\text { Less than secondary education } \\
\text { Secondary education } \\
\text { Post-secondary education }\end{array}$ & $\begin{array}{r}239 \\
1,489 \\
301 \\
\end{array}$ & $\begin{array}{l}23.8 \\
13.4 \\
13.3\end{array}$ \\
\hline $\begin{array}{l}\text { Religious affiliation } \\
\text { Catholic } \\
\text { Other Christians } \\
\text { Islam }\end{array}$ & $\begin{array}{r}334 \\
1,422 \\
258\end{array}$ & $\begin{array}{l}15.3 \\
14.1 \\
16.7\end{array}$ \\
\hline $\begin{array}{l}\text { Wealth quintile***} \\
\text { First } \\
\text { Second } \\
\text { Third } \\
\text { Fourth } \\
\text { Fifth }\end{array}$ & $\begin{array}{l}157 \\
274 \\
428 \\
633 \\
537\end{array}$ & $\begin{array}{l}21.0 \\
16.4 \\
18.5 \\
12.8 \\
10.8\end{array}$ \\
\hline
\end{tabular}

\footnotetext{
${ }^{1}$ Include few cases of Hausa and Fulani who are predominantly resident in the northern part of Nigeria
} 


\begin{tabular}{|c|c|c|}
\hline Characteristics & $\begin{array}{l}\text { Number of women age } 15-24 \\
\text { who had high-risk sexual } \\
\text { intercourse in the past } 12 \text { months }\end{array}$ & $\begin{array}{l}\text { Percentage of young } \\
\text { women age 15-24 who had } \\
\text { high risk sexual } \\
\text { intercourse with a man } \\
10+\text { years }\end{array}$ \\
\hline $\begin{array}{l}\text { Age at sexual debut } \\
\text { Less than } 15 \text { years } \\
15-17 \text { years } \\
18 \text { years and above } \\
\end{array}$ & $\begin{array}{l}298 \\
904 \\
810\end{array}$ & $\begin{array}{l}19.1 \\
15.3 \\
11.6\end{array}$ \\
\hline $\begin{array}{l}\text { Age difference between respondent } \\
\text { and first sexual partner }{ }^{* * *} \\
\text { Less than } 5 \text { years } \\
5-9 \text { years } \\
10 \text { years and above }\end{array}$ & $\begin{array}{r}1,165 \\
316 \\
69 \\
\end{array}$ & $\begin{array}{r}4.1 \\
11.1 \\
85.5\end{array}$ \\
\hline $\begin{array}{l}\text { Frequency of reading newspaper or } \\
\text { magazine** } \\
\text { Never } \\
\text { Less than once a week } \\
\text { At least once a week } \\
\text { Almost everyday } \\
\end{array}$ & $\begin{array}{r}1,134 \\
430 \\
364 \\
91 \\
\end{array}$ & $\begin{array}{l}16.5 \\
11.9 \\
12.6 \\
12.1\end{array}$ \\
\hline $\begin{array}{l}\text { Frequency of listening to radio }{ }^{* * *} \\
\text { Never } \\
\text { Less than once a week } \\
\text { At least once a week } \\
\text { Almost everyday } \\
\end{array}$ & $\begin{array}{l}390 \\
351 \\
622 \\
659 \\
\end{array}$ & $\begin{array}{l}18.5 \\
16.0 \\
14.1 \\
12.1\end{array}$ \\
\hline $\begin{array}{l}\text { Frequency of watching television*** } \\
\text { Never } \\
\text { Less than once a week } \\
\text { At least once a week } \\
\text { Almost everyday } \\
\end{array}$ & $\begin{array}{l}460 \\
335 \\
468 \\
763 \\
\end{array}$ & $\begin{array}{l}20.7 \\
16.7 \\
13.0 \\
11.0\end{array}$ \\
\hline \begin{tabular}{|l|} 
Total $15-24$ \\
\end{tabular} & 2,029 & 14.6 \\
\hline
\end{tabular}

Note:- ${ }^{*} \mathrm{p}<.05 ;{ }^{* *} \mathrm{p}<.01 ;{ }^{* * *} \mathrm{p}<.001$

Table 3. Percentage of young women age $15-24$ who had high-risk sexual intercourse in the past 12 months with a man who was 10 or more years older than them by selected sociodemographic characteristics

The analysis reveals that an intergenerational sexual relationship is more common among rural dwellers than young women who reside in urban areas $(16.0 \%$ vs. $12.5 \%)$. There is a large variation in the prevalence of intergenerational sex by region: about four out of 10 young women in the northern region had intergenerational sex, compared with 11.2 percent of young women in the southern region. Ethnic affiliation of respondent reveals similar result with region of residence. Intergenerational sexual relationship is most prevalent among northern minority young women (20.2 percent) and least among the Yoruba young women (7.0 percent). Intergenerational sexual relationship is more prevalent among young women with less than secondary education (23.8 percent) and least prevalent among young women with secondary education (13.4 percent) and post-secondary education (13.3. percent).

It is evident from the table 3 that young women who had their sexual debut with a first partner that was 10 or more years older than them are more likely to engage in cross 
generational sex. Wealth index is negatively associated with intergenerational sexual behaviour - young Nigeria women from poorer households are more likely to engage in high-risk sexual relationships affairs than their wealthier counterparts. For instance, 21.0 percent of young women age 15 - 24 reported having sexual intercourse with a man 10 years or more their own age as compared with 10.8 percent of their counterparts from the most wealthier households. The prevalence of intergenerational sex declines from 19.1 percent among young women who had their sexual debut before age 15, to 11.6 percent among those who had their first sexual relation at 18 years and older. Intergenerational sexual relationships are more common among young women who are Muslim, ever married, and those who had never read newspapers or magazine, listened to radio or watched television.

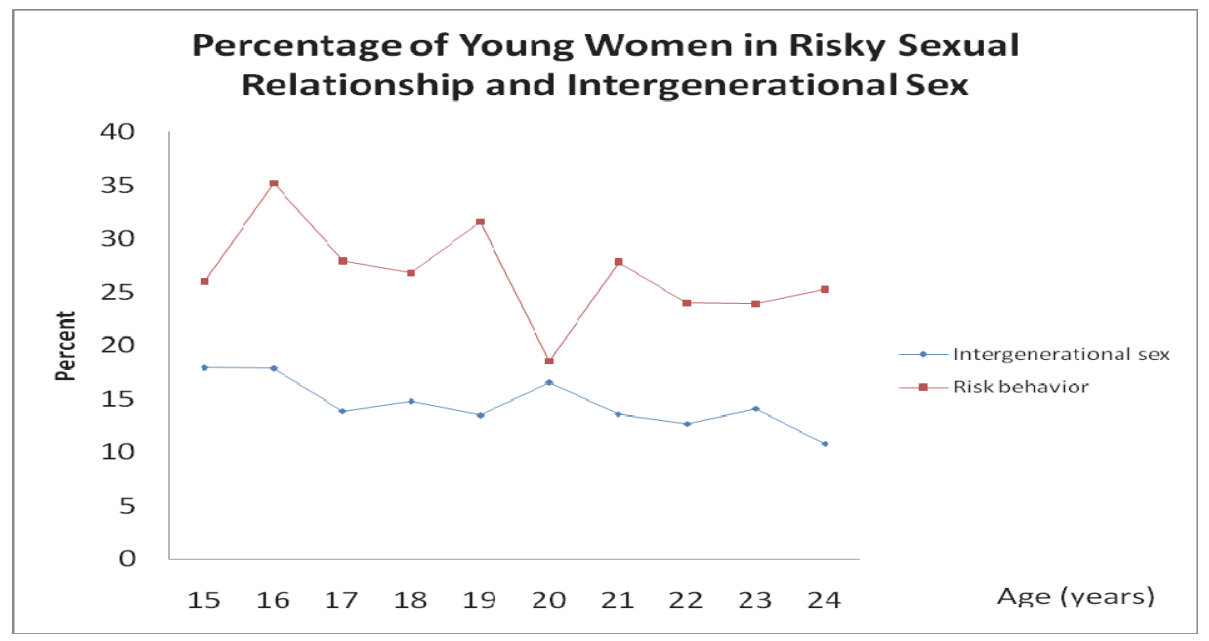

Fig. 1. Percentage of young women in risky sexual relationship and intergenerational sex

\subsection{Multivariate analysis}

Table 4 presents odds ratio for four equations that model the effects of the explanatory variables on the likelihood that Nigerian women (15 - 24 years) would engage in higher-risk sexual relationships with a man 10 years or older. In the first logistic regression model, only education and wealth index were significantly related to young women's engagement in cross generational sexual activities. Young women with secondary school education and those with post-secondary education were less likely than those with less secondary education to have had high-risk sex with a man 10 years or older in the past 12 months (odds ratio of less than 1). For instance, young women with secondary school education and post-secondary school education are 43 percent and 25 percent less likely to engage in intergenerational sex respectively than those with less than secondary education. The finding is statistically significant for the secondary school education. The regression model reveals that young women in the second to fifth quintile of the wealth index are less likely to have engaged in the intergenerational sex as compared with their counterparts in the first quintile of the wealth index. The result was statistically significant for those within the fifth quintile wealth and marginally for those in the fourth quintile wealth index. The other personal attributes added as covariates in the regression equation - individual age - was not significantly associated with intergenerational sex. 


\begin{tabular}{|c|c|c|c|c|}
\hline Background Characteristics & Model 1 & Model 2 & Model 3 & Model 4 \\
\hline $\begin{array}{l}\text { Age Group } \\
15-17 \text { years (ref.) } \\
18-21 \text { years } \\
22-24 \text { years }\end{array}$ & $\begin{array}{l}1.00 \\
0.94 \\
0.79\end{array}$ & $\begin{array}{l}1.00 \\
0.96 \\
0.75\end{array}$ & $\begin{array}{l}1.00 \\
2.06^{* *} \\
2.57^{* *}\end{array}$ & $\begin{array}{l}1.00 \\
2.02^{* *} \\
2.46^{* *}\end{array}$ \\
\hline $\begin{array}{l}\text { Educational Attainment } \\
\text { Les than secondary education (ref.) } \\
\text { Secondary education } \\
\text { Post-secondary education }\end{array}$ & $\begin{array}{l}1.00 \\
0.57^{* * *} \\
0.75\end{array}$ & $\begin{array}{l}1.00 \\
0.60^{* * *} \\
0.87\end{array}$ & $\begin{array}{l}1.00 \\
0.61 \\
1.29\end{array}$ & $\begin{array}{l}1.00 \\
0.68 \\
1.53\end{array}$ \\
\hline $\begin{array}{l}\text { Wealth Index } \\
\text { First quintile (ref.) } \\
\text { Second quintile } \\
\text { Third quintile } \\
\text { Fourth quintile } \\
\text { Fifth quintile }\end{array}$ & $\begin{array}{l}1.00 \\
0.74 \\
0.94 \\
0.65^{\star} \\
0.53^{* *}\end{array}$ & $\begin{array}{l}1.00 \\
0.91 \\
1.11 \\
0.77 \\
0.64 \\
\end{array}$ & $\begin{array}{l}1.00 \\
0.85 \\
0.58 \\
0.86 \\
0.69\end{array}$ & $\begin{array}{l}1.00 \\
0.89 \\
0.70 \\
1.16 \\
1.07\end{array}$ \\
\hline $\begin{array}{l}\text { Place of residence } \\
\text { Urban } \\
\text { Rural }\end{array}$ & & $\begin{array}{l}1.00 \\
0.96\end{array}$ & $\begin{array}{l}1.00 \\
1.36\end{array}$ & $\begin{array}{l}1.00 \\
1.30\end{array}$ \\
\hline $\begin{array}{l}\text { Ethnic Affiliation } \\
\text { Northern Minority } \\
\text { Igbo } \\
\text { Yoruba } \\
\text { Southern Minority } \\
\text { Others }\end{array}$ & & $\begin{array}{l}1.00 \\
0.95 \\
0.34^{* * *} \\
0.50^{* *} \\
1.06\end{array}$ & $\begin{array}{l}1.00 \\
0.73 \\
0.35^{\star *} \\
0.42^{*} \\
0.71\end{array}$ & $\begin{array}{l}1.00 \\
1.10 \\
0.51 \\
0.71 \\
0.83\end{array}$ \\
\hline $\begin{array}{l}\text { Age at sexual debut } \\
\text { Less than } 14 \text { years } \\
15-17 \text { years } \\
18 \text { years and above }\end{array}$ & & & $\begin{array}{l}1.00 \\
0.60 \\
0.30^{* * *}\end{array}$ & $\begin{array}{l}1.00 \\
0.60 \\
0.30^{* * *}\end{array}$ \\
\hline $\begin{array}{l}\text { Age diff. } \mathbf{b} / \mathbf{t} \text { her } 1 \text { st sexual partner } \\
<=4 \text { years } \\
5-9 \text { years } \\
10 \text { years and above }\end{array}$ & & & $\begin{array}{l}1.00 \\
3.41^{* * *} \\
175.25^{* * *}\end{array}$ & $\begin{array}{l}1.00 \\
3.21^{* * *} \\
159.89^{* * *}\end{array}$ \\
\hline $\begin{array}{l}\text { Region } \\
\text { Northern } \\
\text { Southern }\end{array}$ & & & & $\begin{array}{l}1.00 \\
0.63 \\
\end{array}$ \\
\hline $\begin{array}{l}\text { Frequency of watching television } \\
\text { Not at all } \\
\text { Less than once a week } \\
\text { At least once a week } \\
\text { Almost everyday }\end{array}$ & & & & $\begin{array}{l}0.78 \\
0.75 \\
0.54^{*} \\
1.00\end{array}$ \\
\hline -2Log-likelihood (df) & -813.53 & -792.14 & -311.56 & -308.70 \\
\hline
\end{tabular}

${ }^{*} \mathrm{p}<.05 ;{ }^{* *} \mathrm{p}<.01 ;{ }^{* * *} \mathrm{p}<.001 ;+\mathrm{p}<.10 .1 .00=$ reference group

Table 4 . Odds ratios from logistic regression analyses examining associations between selected characteristics and young women engaging in higher-risk sexual relationship with a man 10 years and older (NDHS, 2008) 
While the significant association between wealth index and intergenerational sex disappears on adding place of residence (urban or rural) and ethnicity to the equation in Model 2 the significant relationship between secondary school education and intergenerational sex remains. The analysis shows that place of residence on its own does not significantly influence intergenerational sexual behavior in Nigeria. Ethnicity is significantly associated with intergenerational sex on controlling other variables. The results support the assumption that sexual behavior is guided by the cultural values and norms of the various ethnic groups. Young Yoruba women are 66 percent less likely to have engaged in cross generational sex than those from northern minority ethnic groups. Furthermore, young women from the southern ethnic minorities are significantly less likely to engage in intergenerational sex (odds ratio of 0.50 ) than those of northern minority ethnic groups. The odds of involvement in intergenerational sexual relationship are lower among young women residing in urban areas; the difference is not statistically significant.

In the third model, the significant association between education and intergenerational sex disappears on adding age at sexual debut and age difference between respondent and her first sexual partner while the association for the age becomes statistically significant to the equation in Model 2. In the logistic regression model 3, young women aged 18 - 21 years were (2.06 times) more likely than those 15-17 years to have had higher risk sexual relationship with a man 10 years or older in the past 12 months prior to the interview. Similarly, young women aged $22-24$ years are 2.57 times more likely than those $15-17$ years to have had intergenerational sex in the past 12 months compared with those young women aged 15-17. The results are statistically significant. The odds of engaging in intergenerational sex were lower among Yoruba and southern minority ethnic groups as compared with their northern minority ethnic group. The odds of engaging in higher risk sexual relationship with a man 10 years or older was significantly lower for young women who had first sexual experience 18 years or more as compared with those who started sexual experience before age 15. Furthermore, young women who reported having a partner 5 to 9 years and 10 years or more older at first sex were more likely (OR: 3.41 and 175.25 respectively) to report involvement in risky intergenerational sex, compared to young women whose first sexual partners was younger or less than 5 years older. These differences were statistically significant.

The third model (Table 4) shows that the odds of engaging in intergenerational sex were higher among urban (1.36) young women than their rural counterparts, a finding that is statistically significant. Young women from households classified into second quintile, third quintile, fourth quintile and fifth quintile were less likely to have had intergenerational sex as compared with those from household rank in first quintile. . For instance, young women in the fifth quintile wealth index are 31 percent less likely to have had intergenerational sex compared with those in the first quintile of the wealth index. The differences were not statistically significant.

In the final model, age at sexual debut and age differences between respondent and her first sexual partner remains statistically significantly associated with intergenerational sexual relationships when media exposure variable (frequency of watching television) and region of residence were included into the third equation. The results show that young women aged 18 - 21 years were (2.02 times) more likely than those 15-17 years to have had cross generational sexual relationship in the past 12 months prior to the interview. Similarly, young women aged $22-24$ years are 2.46 times more likely than those $15-17$ years to have had high-risk sexual relationship with a man 10 years or older in the past 12 months before 
their interview compared with those young women aged 15-17. The difference remains statistically significant. Other variables statistically significantly associated with intergenerational sex are age at sexual debut, age difference between respondent and their first sexual partner. As can be seen from table under model 4, young women who reported starting sexual intercourse by age 18 and above are less likely to have had intergenerational sex compared with those who reported starting before age 15. For instance, those who reported their sexual debut age to be 18 years and above are 7-times less likely to have had intergenerational sex as compared with those who reported their sexual debut age at less than 15 years. The difference was statistically significant. The statistical significant association between age difference of the respondent and their first sexual partner and intergenerational sex remains after controlling for all the variables.

Table 4, model 4 shows that young women who reported having a partner 5 to 9 years and 10 years or more older at first sex were more likely (OR: 3.21 and 159.89 respectively) to have had high risk sexual relationship with a man 10 or more years older compared with young women whose first sexual partners was younger or less than 5 years older. These differences were statistically significant. Other factor statistically significantly associated with intergenerational sex is watching television at least once a week as compared to those who reported to "not at all." The results show that young women residing in the southern region are less likely to engage in intergenerational sexual relationship than those living in the northern region. The statistical significance of the ethnicity disappears when variable on exposure to media (television) was introduced. Wealth index remain non-significant from model 2 to 4 while place of residence (urban vs. rural) remain non-significant since it has been introduced into the equation in model 2 .

\section{Discussion}

The growing interest in intergenerational sex is borne out of the concern for the sexual and reproductive health and rights of young women particularly in sub Saharan Africa where the population bears the highest toll of the HIV/AIDS epidemic. From the several iterations of Demographic and Health Surveys and other studies, intergenerational sex is pervasive and this study based on the 2008 Nigeria Demographic and Health Survey confirms the prevalence of the phenomenon in Nigeria. Clearly, from the 2008 NDHS data a sizeable number of young women age $15-24$ years engage in risky sexual behavior that may contribute to the spread of HIV/AIDS. In this study, one-quarter of young women in Nigeria reported having sex with a non-cohabitating and non-marital partners in the last 12 months while 14.6 percent of young women engaged in high risk sexual relationship with a man 10 or more years older than themselves, demonstrating the prevalence of intergenerational sex in the young Nigerian women population and thus the risk of HIV transmission. This estimate seems to be consistent with findings from other studies (Glynn et al., 2001; Kelly et al., 2003; Longfield et al., 2004; NDHS 2003). From this study 16.5 percent of young women aged 15-17 years engaged in intergenerational sex which is almost five-point lower than for women of similar age in the 2003 NDHS. It is too early however to say that the rate is falling. Broadly, this study reveals that the likelihood of engaging in intergenerational sexual relationship varies according to the personal attributes of respondents as well as cultural, attitudinal and behavioral factors.

This study paid particular attention to age of the respondents with regard to sexual risk. The practice of intergenerational sex decreases with age. The study revealed that 16.5 percent of 
young women age 15-17 years, 15.2 percent of those age 18 - 21 years and 12.6 percent of their older peers aged 22-24 years had engaged in higher-risk sexual behaviour in the 12 months with a man 10 years or more years older. The fact that the practice is commonest among 15-17 years is suggestive that the young women are vulnerable to inducements or coercion and those older girls bear the pressure for sex from the older men better. Basically, the younger girls may have little or no knowledge of the implications of their actions; cannot effectively assess the risk involved in the sexual relationship neither do they have the skill to negotiate safer sex. Most girls in this age group are preys and the predators have not spared them. The implications are multiple but essentially speak to the need for the commencement of reproductive health education and life skills programme for young girls early enough so that they are better placed to protect themselves. This is especially important for out - of school girls as it is assumed that in some of our schools family life education is taught to young people. It is similarly essential to pay particular attention to young girls in the rural areas as intergenerational sexual relationship is more common among rural dwellers than young women who reside in urban areas. Another major approach would be to work directly with men to challenge the socio-cultural norms and perceptions that allows for and sanction engagement in intergenerational sex (Leclerc - Madlala 2002, 2003).

The expected result from the two recommended approaches above is to help young girls to increase the age at sexual debut significantly so that they can make informed decision about sex and how to protect themselves. As this study also shows that the odds of engaging in higher risk sexual relationship with a man 10 years or older was significantly lower for young women who had first sexual experience 18 years or more as compared with those who started sexual experience before age 15. The likelihood of having intergenerational sex tends to increase with intergenerational first sexual experience which has been reported to be linked with poor reproductive health outcomes. For instance, examining a longitudinal, representative sample of adolescents in the United States, Ryan and others found that women who initiated sex before age 16 with an older partner had a greater likelihood of testing positive for an STI in young adulthood. It is evident from the paper that intergenerational sexual relation varies according to personal, cultural and behavioral attributes of the respondents. These attributes should be considered when designing programs to promote safe and healthy sexuality and effective HIV/AIDS/STIs prevention,. In addition, the study suggests that several young Nigerians are vulnerable to HIV infection through high risk sexual behaviour and relatively low levels of condom use. HIVprevention efforts should target the entire young population, rather than attempting to identify and focus attention only on high risk groups.

Another significant finding from this study is educational attainment. This is particularly important as we look at environment and structural factors that predispose to poor health outcomes importantly in our case the risk of HIV infection. The study shows that young women with secondary school education and those with post-secondary education were less likely than those with less secondary education to have had high-risk sex with a man 10 or more years older in the past 12 months. The implication is that the more educated the girl child is the higher the likelihood of better health outcomes. Nigeria has Universal Basic Education (UBE) programme which ensures at least nine (9) years of formal education, it is free and compulsory - compelled by law but in practice not enforced. In effect, Nigeria can greatly reduce the prevalence of intergenerational sex by enforcing the law that established Universal Basic Education. 
In another age and educated related finding, the result reveals that age has a positive relationship with intergenerational sex particularly in models three and four, the result indicate that older young women who engage in high-risk sexual relationship may be the higher education students. Although the relationship between education and intergenerational sex become non-significant at multivariate analyses in equation 3 and 4, the higher prevalence of intergenerational sex among those in post-secondary schools may be due to the fact that young women exchange sex to get funds to cover education-related expenses and gain connections in social networks (Barker and Rich, 1992; Kaufman et. al., 2001; Meekers and Calves, 1997). This is a converse relationship when compared with young women in intergenerational sex. The older women are not 'victims' in the relationship, as they actively search for and establish such relationships to their advantage; studies reveal 'that many play active roles in seeking and exploiting relationships with older men and do not perceive themselves as victims' (Silberschmidt \& Rasch 2000, Leclerc-Madlala 2003, Nkosana 2006)

The practice is consistent within the context of growing economic inequalities and cultural expectations for men to give and women to receive a compensation for sex, paves way for young women to gain materially, affirm self-worth, achieve social/educational goals, increase longer-term life chances, or otherwise add value and enjoyment to life.

It is important to mention it for affirmation, that poverty plays an important role in intergenerational sex such as in commercial sex work. The study reveals, from the regression model, that young women in the second to fifth quintile of the wealth index are less likely to engage in the intergenerational sex as compared with their counterparts in the first quintile of the wealth index. This confirms the link between poverty and risky sexual behavior - such as intergenerational sex, survival sex and prostitution. Young women's vulnerability to HIV is fueled by financial dependence and economic stress makes them susceptible to involvement in intergenerational relationship. As earlier mentioned access to education is a major route out of ongoing poverty and dependence. (Leclerc-Madlala 2003) Greater opportunity should also be given to women empowerment programmes (Odutolu et al 2003).

Broad categories of Northern and Southern regions rather than six geo-political regions and states were included in the models, because the number of cases was too low to allow for either region or state specific analyses. Future in-depth studies should therefore be carried out within region and states because of the heterogeneity of the country. Further evidence of Nigeria heterogeneity exists even within ethnic groups, such as the Yoruba who are made up of sub-ethnic groups with distinctive cultures; therefore, it is important to use caution when making generalizations about Nigerian populations. Although this study examined risk factors on a national level in Nigeria, some of the non-significant associations may have been a result of these intraregional differences, leading to a null association. Quantitative and qualitative state or region-specific studies should be carried out to probe the association between intergenerational sex, individual attributes, behavior and cultural factors so as to help programme implementers and policy makers targeting high risk groups.

The regional patterns of intergenerational sexual relationships found in this study suggest ethnicity may be an important factor to be considered when studying adolescents or young people's sexuality and sexual behavior. Ethnicity is significantly associated with intergenerational sex on controlling other variables. The results support the assumption that sexual behavior is guided by the cultural values and norms of the various ethnic groups. Young Yoruba women are 66 percent less likely to have engaged in cross generational sex 
than those from northern minority ethnic groups. However, this influence of cultural norms may be changing due to globalization and education, especially in the cities where people are more likely to abandon traditions because of the heterogeneity of populations. Still for many Nigerians, ethnic affiliation, which is usually a regional element, means shared language and norms governing behaviour and sexuality issues. The results of this study support the view that intergenerational sexual relationships is a function of varied sociocultural factors including religion, level of exposure to formal education, urban-rural residence among others. Based on the notion that intergenerational sex predisposes to HIV infection, it is important for government and other programme planners to factor ethnic differences to HIV prevention programmes and make them more specific to the needs of the various ethnic groups and regions. The bane of HIV programming in Nigeria has always been one size fits all concepts and interventions. It is time that the interventions are evidence based and appropriately targeted.

The study results shed further light as regards the challenges facing programmes aimed at improving the reproductive health situation of adolescents and young adults in Nigeria, as well as opportunities for intervention. One major challenge is the sizeable number and diverse nature of factors that appeared to influence young women high risk behaviour. Some of these were particular characteristics of the environment in which they are reared. Therefore, a single, easy-to-implement intervention is unlikely to provide a solution to the risky behavior being engaged upon and its attendant consequences of vulnerability to STI and HIV/AIDS transmission in Nigeria. This is consistent with conclusion that when in a given setting and a multitude of correlates exists, each having a small impact on sexual behaviour, rather than a few correlates, each having a large impact, a single "magic bullet" is unlikely to be found to change adolescent sexual behaviour significantly.

These results have important policy implications. Because factors associated with intergenerational sexual behaviour among Nigerian young women vary according to education, ethnic affiliation, age, age at sexual debut, age difference between respondent and her first sexual partner, exposure to media and wealth quintile, programs may need to position intervention differently for different target populations. The study established that there is a relatively high risk sexual activity thus making the sampled population vulnerable to HIV infection. In addition, unwanted pregnancy could lead to termination of education especially the sexual partner refuses to claim the pregnancy; as a result, young women could face a bleak economic and social future. Therefore, behavioural change communication activities should be strengthened with extensive education on safe-sexual behaviour through culturally appropriate messages, as is currently undertaken by various NGOs in the country. In particular, more effort should be made to reach the young women from poor household and rural areas, who typically had earlier sexual debut and also tended to be more engaged in cross-generational sex, with adequate information on behavioural change, prevention of unwanted pregnancy and protection from sexually transmitted infections, including HIV/ AIDS.

Although this research does not focus on the relationships between intergenerational sex and STI/HIV/AIDS situation in Nigeria, it highlights the importance of intergenerational sexuality in contributing to the spread of STI/HIV/AIDS especially in cultures where women are subjugated to male social hegemony. Furthermore, the ethnic differences in intergenerational sex observed in this study are consistently found in other studies on sexual and reproductive behavior in Africa. Since little is known on how cultural norms and 
values affect intergenerational sexual behaviors in Nigeria, more research is required to explore these relationships.

The quality of self-reported information particularly the dependent variable may be unreliable. If anything, however, such sexual behavior as high risk sex, ever paid for sex, condom use at last sex and history of STDs would be underreported, biasing the association towards the null. Therefore, any significant association found may be an attenuated one.

\section{Conclusion}

This study confirms the prevalence of intergenerational sex in Nigeria and identifies associated factors. It assuages that the practice may promote the spread of HIV infection among Nigeria's teeming youth population leading to HIV infected young women bearing the burden of the disease. The messages are clear that delayed onset of sexual debut; education; women economic empowerment, increased life options for women and working with men to challenge the socio-cultural norms and perceptions that allows for and sanction engagement in intergenerational sex would go a long way to reduce the practice and lead to improvement in the health outcomes of the young women including reduction in HIV infection in the group. The authors have suggested several policy options but policies need to be put in context within the different regions of Nigeria and the health and sustainable development objectives of the country. Importantly, more qualitative studies should be carried out to identify other social factors promoting the practice in Nigeria and studies directed at intergenerational sex and HIV infection would definitely be very instructive.

There is need to make concerted efforts with programmatic responses to counter power imbalances from gender, age and economic or materials differences between young women and their older male partners. As programmatic responses are mounted, it is important that they are accompanied by intervention research to test their feasibility and ultimately, their impact on reducing intergenerational sex or the inherent power imbalances therein, that facilitate vulnerability of the young women particularly HIV transmission and unwanted pregnancy. Furthermore, the authors suggested a number of policy issues, any process to garner policy support must also be accompanied by policy research to document and analyze the most salient elements of the resulting social change process.

\section{Acknowledgement}

The authors acknowledge the helpful comments of Dr. Gbenga Ishola of Jhpiego in the preparation of this article. Dr. Dayo Adeyemi of the MEASURE Evaluation/JSI contributed immensely during the multivariate analysis. The contribution of Adrienne Cox and Noureddine Abderrahim both of ICF Macro in the construction of the outcome variable added value to the in-depth knowledge of analysis in the use of NDHS data. Finally, we thank the ICF Macro and National Population Commission, Nigeria for making the data of the Nigeria Demographic and Health Survey (NDHS) available for use. The opinions expressed in this article are solely those of the authors and do not represent the views of their institutions.

\section{References}

Abang, Mkpe (1996). Promoting HIV/AIDS prevention on Nigerian campuses: Students take the lead AIDScaptions 111(3). 
Akuffo, FO (1987). Teenage pregnancies and school drop-outs: The relevance of family life education and vocation training to girls' employment opportunities. In Christine Oppong, ed. Sex roles, population and development in West Africa. Portsmouth, NH. Heinemann

Allison P. (1984). Event History Analysis: Regression for Longitudinal Data. Sage. pp 23-34

Barker, Gary Knaul and Susan Rich. 1992. "Influences on Adolescent Sexuality in Nigeria and Kenya: Findings from Recent Focus-Group Discussions." Studies in Family Planning 23: 199-210.

Blanc AK (2001): The effect of power in sexual relationships on sexual and reproductive health: an examination of the evidence. Studies in Family Planning, 32 (10):189-213.

Calves, Anne Emmanuele, Gretchen T. Cornwell, and Parfait Eloundou Enyegue. (1996). Adolescent Sexual Activity in Sub-Saharan Africa: Do Men Have the Same Strategies and Motivations as Women? University Park, PA: Population Research Institute.

Federal Ministry of Health (2009) National HIV/AIDS and Reproductive Health Survey (NARHS 2007), Abuja Nigeria

Feldman, Douglas A., Peggy O'Hara, K.S., Baboo, Ndashi W. Chitalu, and Ying Lu. (1997): HIV prevention among Zambian adolescents: Developing a value utilization/norm change model. Social Science and Medicine, 44(4): 455-468

Gage, AJ. (1998). Sexual activity and contraceptive use: The components of the decision making process. Studies in Family Planning, 29(2): 154-166

Glynn, J.R, Carael, M., Auvert, B., Kahindo, M., Chege J., Musonda, R., Kaona, F., and Buve, A.(2001). Why do young women have a much higher prevalence of HIV than young men? A study in Kisumu, Kenya, and Ndola, Zambia. AIDS, 15 (Supplement 4): 51-60.

Gomez, Anu Manchikanti, Ilene S. Speizer, Heidi Reynolds, Nancy Murray and Harry Beauvals (2008). "Age difference at sexual debut and subsequent reproductive health: Is there a link” ? Reproductive Health, 2008 5:8 doi.10. 1186/742-4755-5-8

Gorgen, Regina, Mohamed Yansane, Michael Marx, and Dominique Millimonunou. (1998). "Sexual Behaviour and Attitudes Among Unmarried Urban Youths in Guinea. International Family Planning Prespectives, 24(2): 65-71.

Gregson S, Nyamukapa CA, Garnett GP, Mason PR, Zhuwau T, Carael M, Chandiwana SK, and Anderson RM (2002): Sexual mixing patterns and sex-differentials in teenage exposure to HIV infection in rural Zimbabwe. Lancet, 359:1896-1903. (5)

Gregson, Simon, Constance A. Nyamukapa, Geoffrey P. Garnett, Peter R. Mason, Ton Zhuwau, Michel Carael, Stephen K. Chandiwana, and Roy M. Anderson. (2002). "Sexual Mixing Patterns and Sex- Differentials in Teenage Exposure to HIV Infection in Rural Zimbabwe." The Lancet 359: 1896-1903.

Jewkes R, Levin J, Mbananga N, and Bradshaw D (2002): Rape of girls in South Africa. Lancet, 359 (6):319-320.

Jones, L. (2006). Sexual decision-making by urban youth in AIDS-afflicted Swaziland. African Journal of AIDS Research, 5(2): 145-157.

Kaufman CE, Stavrou SE (2002): "Bus Fare, Please": The Economics of Sex and Gifts Among Adolescents in Urban South Africa. In Policy Research Division Working Papers. New York: Population Council; (12) 
Kelly, R., Gray, R., Sewankambo, N., Serwadda, D., Wabwire-Mangen, F., Lutalo, T. \& Wawer, M. (2003). Age differences in sexual partners and risk of HIV-1 infection in rural Uganda. Journal of Acquired Immune Deficiency Syndrome, 32(4): 441-451.

Kirby Douglas (1999). Antecents of Adolescents Sexual Risk Taking, Pregnancy and childbearing: Implications for Research and Programs. Washington, DC: National Campaign to Prevent Teen Pregnancy.

Komba-Malekela, Betty and Rita Liljestorm (1994). Looking for men. In Zubeida TumboMasabo and Rita Liljestorm, eds, Chelewa, chelewa. The dilemma of teenage girls. The Scaninavian Institute of African studies

Langeni, T. (2007). Contextual factors associated with treatment-seeking and higher-risk sexual behaviour in Botswana among men with symptoms of sexually transmitted infections. African Journal of AIDS Research 6(3): 261-269.

Leclerc-Madlala, S. (2002). On the virgin cleansing myth: gendered bodies, AIDS and ethnomedicine. African Journal of AIDS Research, 1: 87-95.

Leclerc-Madlala, S. (2003). Transactional sex and the pursuit of modernity. Social Dynamics, 29(2): 213-233.

Longfield, K., Glick, A., Waithaka, and Berman, J. (2004) Relationships between older men and younger women: Implications for STIs/HIV in Kenya. Studies in Family Planning, 35(2): 125-134.

Luke, N. (2003). "Age and economic asymmetries in the sexual relationships of adolescent girls in sub-Saharan Africa." Studies in Family Planning, 34(2): 67-86.

Luke N (2005): Confronting the 'sugar daddy' stereotype: age and economic asymmetries and risky sexual behavior in urban Kenya. International Family Planning Perspective, 31 (7):6-14.

Luke N, and Kurz KM (2002): Cross-generational and Transactional Sexual Relations in SubSaharan Africa: Prevalence of Behavior and Implications for Negotiating Safer Sexual Practices. Washington, D.C.: Population Services International; (8)

Machel, J. (2001). Unsafe sexual behaviour among schoolgirls in Mozambique: a matter of gender and class. Reproductive Health Matters 9(17): 82-90.

MacPhail C, Campbell C. 'I think condoms are good but, aai, I hate those things': condom use among adolescents and young people in a Southern African township. Social Science and Medicine 2001; 52 (11): 1613 - 1627

Matasha, E., T. Ntembelea, W. Saidi, J. Todd, B. Mujaya and L., Tendo-Wambua (1998). Sexual and reproductive health among primary and secondary school pupils in Mwanza, Tanzania.: Need for Intervention. AIDS Care, 10(5): 572-582

Mclean, Polly (1995). Sexual behaviours and attitudes of high school students in the Kingdom of Swaziland. Journal of Adolescent Research, 10(3): 400-420

Meekers, Dominique and Anne-Emmanuele Calves. (1997a). "'Main' Girlfriends, Girlfriends, Marriage, and Money: The Social Context of HIV Risk Behaviour in Sub-Saharan Africa." Health Transition Review 7(Supplement): 316-375.

Meekers, Dominique and Anne-Emmanuele Calves. (1997b). Gender differentials in adolescent sexual activity and reproductive health risks in Cameroon Washington, Dc. PSI Research Division Working Paper No. 4. 
Mensch BS, Lloyd CB (1998): Gender differences in the schooling experiences of adolescents in low-income countries: the case of Kenya. Studies in Family Planning, 29:167-184. (11)

Moore, AM and Biddlecom, A. (2007). Transactional sex among Adolescents in Sub-Saharan Africa amid the HIV Epidemic. Paper presented at the Annual Meetings of the Population Association of America, New York, March 29 - 31.

National Population Commission (NPC) [Nigeria] and ICF Macro. 2009. Nigeria Demographic and Health Survey 2008. Abuja, Nigeria: National Population Commission and ICF Macro

Nkosana, J. (2006). Intergenerational relationships in urban Botswana. Unpublished PhD thesis, Department of Public Health, University of Melbourne.

Nkosana, J. and Rosenthal, D. (2007). The dynamics of intergenerational sexual relationships: the experience of schoolgirls in Botswana. Sexual Health, 4(3): 181-187.

Nyanzi S, Pool R, and Kinsman J (2000). The negotiation of sexual relationships among school pupils in south-westernUganda, AIDS Care; 13(1): 83-98

Nyanzi and Kinsman 2001

Odutolu Oluwole, Adebola Adedimeji, Omobola Odutolu, Olatunde Baruwa and Funmilayo Olatidoye. (2003) Economic Empowerment and Reproductive Behaviour of Young Women in Osun State. Nigeria African Journal of Reproductive Health, 7 (3): 92-100

Orubuloye I, Caldwell J, and Caldwell P. (1992). Diffusion and focus in sexual networking: identifying partners and partners' partners. Studies in Family Planning, 23(6) :343351

Poulin, M. (2007). "Sex, money, and premarital partnerships in southern Malawi." Social Science and Medicine, 65: 2383-2393.

Ryan, S.; Franzetta, K.; Manlove, JS. and Schealer, E (2008): “Older Sexual Partners during adolescence: links to reproductive health outcomes in young adulthood. Perspect Sex Reproductive Health, 40: 17 - 26.

Silberschmidt, M., \& Rasch, V. (2000) Adolescent girls, illegal abortion and 'sugar daddies' in Dares Salaam: Vulnerable victims and active social agents. Social Science and Medicine 52: 1815-1826.

Stavrou, SE and Kaufman, CE (2000). „Bus fare please“ The economics of sex, gifts and violence among adolescents in urban South Africa. Paper presented at the Annual Meetings of the Population Association of America, Los Angeles, March 23 -25.

UNAIDS (2004), Facing the Future Together: Report of the Secretary Generals' Task Force on Women, Girls, and HIV/AIDS in Southern Africa. Joint United Nations Programme on HIV/ AIDS (Geneva: UNAIDS, 2004).

UNAIDS (2006), Report on the Global AIDS Epidemic (Geneva: UNAIDS, 2006)

Weiss, Ellen, Daniel Whelan and Geeta Rao Gupta (1996). Vulnerability and opportunity. Adolescents and HIV/AIDS in the developing world. Washington, Dc: International centre for Research on Women.

Wojciki, JM. (2005). Socioeconomic status as a risk factor for HIV infection in women in East, Central and Southern Africa: a systematic review. Journal of Biosocial Science, 37:136. 
Wood K, Maforah F, and Jewkes R (1998): "He forced me to love him": putting violence on adolescent sexual health agendas. Social Science Medicine, 47 (13):233-242 (13) 


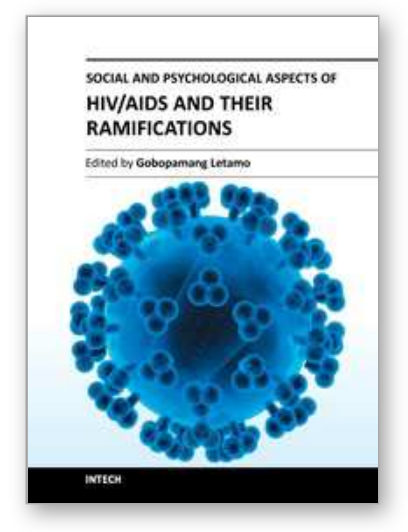

\author{
Social and Psychological Aspects of HIV/AIDS and their \\ Ramifications \\ Edited by Prof. Gobopamang Letamo
}

ISBN 978-953-307-640-9

Hard cover, 312 pages

Publisher InTech

Published online 26, October, 2011

Published in print edition October, 2011

This book has assembled an array of chapters on the social and psychosocial aspects of HIV/AIDS and their impact on HIV/AIDS and related behaviours. The book addresses key areas of HIV and AIDS, including, but not in any way limited to, care-seeking behaviour, adherence, access, psychosocial needs and support services, discrimination and the impact the epidemic has on various sectors of the economy. The book has seventeen chapters; seven chapters deal with social aspects of HIV/AIDS, four with psychosocial aspects of HIV/AIDS, and the remaining six chapters with the impact of social and psychosocial factors on HIV/AIDS and related behaviours. The book is an essential reading for academics, students and other people interested in the field of HIV and AIDS.

\title{
How to reference
}

In order to correctly reference this scholarly work, feel free to copy and paste the following:

Oyediran, K.A., Odutolu, O. and Atobatele, A.O. (2011). Intergenerational Sexual Relationship in Nigeria: Implications for Negotiating Safe Sexual Practices, Social and Psychological Aspects of HIV/AIDS and their Ramifications, Prof. Gobopamang Letamo (Ed.), ISBN: 978-953-307-640-9, InTech, Available from: http://www.intechopen.com/books/social-and-psychological-aspects-of-hiv-aids-and-theirramifications/intergenerational-sexual-relationship-in-nigeria-implications-for-negotiating-safe-sexual-practices

\section{INTECH}

open science | open minds

\author{
InTech Europe \\ University Campus STeP Ri \\ Slavka Krautzeka 83/A \\ 51000 Rijeka, Croatia \\ Phone: +385 (51) 770447 \\ Fax: +385 (51) 686166 \\ www.intechopen.com
}

\author{
InTech China \\ Unit 405, Office Block, Hotel Equatorial Shanghai \\ No.65, Yan An Road (West), Shanghai, 200040, China \\ 中国上海市延安西路65号上海国际贵都大饭店办公楼405单元 \\ Phone: +86-21-62489820 \\ Fax: +86-21-62489821
}


(C) 2011 The Author(s). Licensee IntechOpen. This is an open access article distributed under the terms of the Creative Commons Attribution 3.0 License, which permits unrestricted use, distribution, and reproduction in any medium, provided the original work is properly cited. 